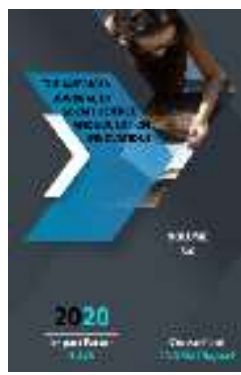

\title{
Medialinguistics: A Comprehensive Approach To Media Training
}

\author{
Saodat Khidoyatovna Shamaksudova \\ Senior Lecturer, Department Of "Uzbek Language And Literature", Faculty Of Print Media \\ And Publishing, University Of Journalism And Mass Communication Of Uzbekistan
}

Journal Website: http://usajournalshub.c om/index,php/tajssei

\section{ABSTRACT}

The article discusses the concept of media text, areas of their study, aspects of media linguistics and the study of media language. The methodological apparatus, internal structure and main sections of media linguistics are considered. As a result of the rapid development in recent years of the level of study of the media in world linguistics, it became known that the language of the media is studied on the basis of its many connections and functions. The research material was collected using Uzbek and foreign literature. The aim of the work is to show the need for an integrated approach to the study of media texts, which is the main object of research in media linguistics.

\section{KEYWORDS}

Media linguistics, media text, verbal language, phonological, syntagmatic and stylistic features, cultural linguistics, discourse analysis, cognitive, semantic.

\section{INTRODUCTION}

The level of media study in world linguistics has been rapidly developing in recent years. Currently, the language of the media is being studied in terms of its many connections and functions. This includes media language and thinking, media language and society, media language and cultural studies, media language and politics.
Of course, new approaches to the language of the media are associated not only with general trends in the development of world linguistics. The changing tasks of the media, the transitional processes taking place in society have a direct impact on this. This makes us understand the language of the media, taking into account the processes taking place in society from the point of view of culture, 
politics and ideology. The verbal language used in interpersonal communication manifests its main features in a unique way in the process of mass communication. $(3,19$.)

The language of publicistic and artistic works of that period can be studied for the purpose of scientific study of the state of the language in a particular historical period, its specific features, lexical, phonetic and grammatical variations, general and various aspects of the language with its current state. In this case, the language of printed materials, works of art, written monuments of that period serves only as material for research with the same purpose. In describing and studying the history of the language, this path has been preserved as the oldest and strongest linguistic tradition. A lot of research has been carried out in this direction in Uzbek linguistics. Among such works are famous linguists A. Rustamov, G. Abdurakhmanov, F. Abdullaev, H. Doniyorov, B. Bafoev, F. Ishakov, B. Turdialiev, T. Dzhumaev, Sh. Shoabdurakhmonov, $M$. Askarova, A. Can be shown many works by Khodzhiev, A. Gulomov ${ }^{1}$ and others.

The main goal of studying the language of the media in the "stylistic aspect" is, of course, different. The problem here is that the language has different functions. The famous scientist G.O. Vinokur notes that the communicative and expressive functions of language began to differ from linguistics in ancient times. But human language wants to express not only related concepts and their

1 Abdurahmonov G., Rustamov A. Grammatical features of Navoi language.-T: Science, 1984., Abdullaev F. On the harmony of sounds in the language of Alisher Navoi's works // OTA., 1996, №5., Doniyorov H. Alisher Navoi and Uzbek literary language. -T., 1972., Bafoev B. Vocabulary of Navoi's works. -T: Fan, 1983., Ishakov F. Gulkhani's work "Zarbulmasal". -T: Fan, 1976., Turdialiev B. Hamza logical relationships, but also the speaker's relationship to his own thought; I want to express not only what I say, but also myself, and in this way the psychological factor is added to the logical factor, saturating it in every sense. " $(4,35$.)

In modern literature on linguistics, four to five functions of language are mainly noted. For example, V.A. Avrorin emphasizes the need to distinguish between communicative (means of communication), expressive (expression of ideas), constructive (formation of ideas), accumulative (accumulation, storage of social experience and knowledge) functions of language. $(1,44$.

\section{THE MAIN PART}

Therefore, when studying the language of the media, it has become a tradition to study it primarily from a methodological (stylistic) point of view. A number of linguists have worked on the language and style of the media. They include Vinokur G.O., Vakurov V.N., Solganik G.Ya., Sadullaev G.O., Abdusaidov A., Abdurakhmonov A., Shomaksudov A., Rasulov I., Kungurov R., Rustamov H., Kudratov. T., Toshaliev I., Tozhiev Yo. and many other works can be cited as examples.

In recent years, the concept of media text has been widely used in the modern information world. The concept of media text emerged in the twentieth century as a new hierarchy of

and Uzbek literary language. -T: Fan, 1981., Jumaev T. Linguistic features of the works of Umar Baki. NDA., -T., 1997., Shoabdurahmonov Sh., Asqarova M., Hojiev A. and others. Modern Uzbek literary language. -T .: Teacher, 1990., Gulomov A., Askarova M. Modern Uzbek literary language. Syntax. -T .: Teacher, 1978. 
text associated with film, radio, television, video, Internet and mobile phones, replacing traditional printed text as a result of the rapid development of the media. The concept of media text is widely used mainly in the field of media.

In this sense, the main attention was paid to the study of media texts. A number of studies have been carried out in recent years. Volkov A.A., Volodina M.N., Demyankov V.N., Dobrosklonskaya T.G., Ivanova L.Yu., Klushina G.I., Kobozeva I.M. Kochiboev A., Makhmudov N., Melnik G.S., Tepyashina A.N., Mirsanov G., Pardaev A., Ruziev F., Makhamadaliev H., Smetanina S.I., Solganik G.Ya., Shevelevsky I. M., Bakieva G.Kh., Teshabaeva D.M., Israil M.I., Tashmukhamedova L.I. and a number of linguists have studied media texts and their features in their research.

\section{RESULTS AND DISCUSSION}

New approaches to the study of media texts are associated not only with general trends in the development of world linguistics. Changing tasks of mass communication, transitional processes taking place in society also have a direct impact on this. This makes us understand the text of mass communication, taking into account the processes taking place in society from the point of view of culture, politics and ideology. $(2,8$.

The emergence of speech linguistics, which studies language as speech, that is, a dynamic phenomenon, also led to radical changes in world linguistics.

The verbal language used in interpersonal communication shows its main features in the process of mass communication. $(4,11$.)
Sociolinguistic, cognitive, semantic, psycholinguistic, pragmatic and cultural, discursive principles open up a wide range of possibilities for a complete understanding of the unique sociolinguistic phenomenon called the language of the media. The study of the media language in such aspects also requires the study of important features of the processes of speech influence. $(3,19$.)

An integrated approach to media research is currently being developed. This educational and scientific direction in German is called Medienwissenshaft, and in accordance with the English scientific traditions of medialingustic - medialinguistics. Within the framework of this new direction of linguistics, various areas of study of media texts were combined. All of them represent the dialectical integrity of linguistic and media characteristics, and three scales of median speech are manifested: a text-to-word scale, videotape or graphic images of words, and the volume of the soundtrack (volume of sound synchronization).

Media texts are considered within the framework of different schools and directions: from the point of view of sociolinguistics, functional methodology, discourse theory, content analysis, cognitive linguistics, rhetorical criticism. The attention of researchers is attracted by a variety of topics: these are methods for determining the functional and methodological status of the media language, as well as methods for describing various media texts and linguistic media technologies of the influence and influence of sociocultural factors on media.

An analysis of the activities of representatives of this field allows us to emphasize that at the end of the twentieth century, all the necessary 
conditions were created for the formalization of knowledge and experience accumulated in the study of the language of the media in an independent scientific direction. In other words, the total volume of research in the field of media texts has reached a "critical peak", which has proposed a new quality of research in this area - an integrated approach to media linguistics, including the study of media language.

The term "media linguistics" is derived from its resemblance to a number of related terms used in new academic disciplines that are emerging in the discipline field. The term itself combines two main components - "media" and "linguistics", and the subject of this new science is the study of the function of language in the field of mass communication. That is, media linguistics studies a specific area of speech use - the language of the media. (5, 509.) Therefore, media linguistics is the field of study of media texts.

The ways of creating and distributing media texts depend on their linguistic volumetric characteristics, functional-genre classification, phonological, syntagmatic and stylistic features, interpretive properties, cultural characteristics, ideological modeling, pragmalinguistic value.

The methodological apparatus of media linguistics unites the achievements of all directions in the study of media texts. These include discourse analysis, functional stylistics and cultural linguistics (language culture). (3, 28.)

The next factor that makes it possible to distinguish media linguistics as a separate scientific field is its internal structure, which, although it is at the stage of formation today, is a more stable set of components. Currently, there are six main sections of media linguistics, the structure of which is built around the following main themes:

1. Determine the internal linguistic status of the language of the media, the description of the language-speech, text-discourse in terms of the basic paradigm;

2. The possibility of functional and methodological differentiation of media discourse, the ability to classify texts according to the level at which they perform the main functions of language and distribution channel (press, radio, television, Internet);

3. Typology of media performances, genre classification of media texts, determination of the main types of texts - news, analytical information and reviews, journalism, advertising;

4. Linguistic and stylistic features of the main types of media texts;

5. Extralinguistic components of media discourse, for example: production, distribution and perception of media texts, socio-cultural and ideological context, peculiarities of media interpretation, metainformation, culturally specific features;

6. Linguistic technologies that affect individual and public consciousness (linguistic component of propaganda, manipulation methods, methods of political information and information management, public relations).

Although the terminological apparatus of media linguistics is now being formed, we can identify a number of specific terms that are widely used to describe the functioning of the language in the media. Basically, these are words and phrases formed on the lexical basis 
of the media. For example, media text, media language, media landscape, features and characteristics of media language, linguistic technologies of influence, and much more. Like other sciences that arise at the intersection of disciplines, media linguistics naturally combines the features of two scientific disciplines: on the one hand, it relies on a generalized base of linguistic research, on the other hand, it is part of the general system of media communications - a new scientific direction. Engaged in a comprehensive study of the media. $(5,509$.)

Today, all methods of text processing are used to study media texts: from traditional methods of structural and structural analysis to the analysis of discursive, sociological and cultural studies. Such a broad methodological base was formed primarily as a result of an interdisciplinary study of media texts. The combination of various methods for analyzing media texts in the field of media linguistics to obtain a comprehensive understanding of the real features of the media, its style, the characteristics of individual and public consciousness, methods of interaction between oral and media, ideological modality, the role of culturally significant components allows.

Among the most effective and common methods for studying media text are the following:

1. A whole group of methods of linguistic analysis, allowing to determine the main features and characteristics of the text at different levels of language: lexical, syntagmatic (compatibility), stylistic (using tropes, comparisons, metaphors and other stylistic means), sociolinguistic.
2. Content analysis or a method of content analysis based on statistical calculation of specially selected text units.

3. The method of discourse analysis, based on a discursive concept and allowing to determine the ratio of the linguistic and extraistic sides of the text.

4. The method of critical linguistics (or rhetorical criticism), revealing the hidden political and ideological component of the media text.

5. The method of cognitive analysis, based on the study of conceptual aspects of popular texts and aimed at determining the relationship between reality and its media representations.

6. And, finally, the method of linguoculturological (linguoculturological) analysis, based on the identification of culturally significant components of the text, such as reality, assimilated, foreign words, equivalent lexical units, etc. about the features.

Obviously, the group of methods of linguistic analysis is important in the field of media linguistics.

The methods of linguistic analysis are a group of traditional methods of semantic, stylistic, morphological, syntactic analysis of media texts in linguistics. This study of media texts has a long and fruitful tradition. $(6,37$.

Particularly important is the method of continuous text analysis, which makes it possible to determine the rules for constructing a media text at the syntagmatic and methodological level. At the syntagmatic level, the analysis reveals a stable paradigm of consistency characteristic of a particular type of text. For example, the syntagmatic form of news (informational texts) is based primarily 
on verbal expressions. Syntagmatic analysis of media texts also makes it possible to single out all groups of continuous thematic sets, which are always repeated when a certain media peak is illuminated.

The method of stylistic analysis is also of great importance, since its goal is to identify various methodological tools and their role in the implementation of the general communicative point of view of the media text. It is known that the style of speaking in the media is very rich and colorful. Texts related to information analysis, journalism and advertising are filled with patterns, comparisons, metaphors and other stylistic tools used to influence audiences. At the same time, special attention is paid to the use of metaphors, their ability to accurately reflect the truth through vivid and memorable images is widely used in journalistic practice around the world. Examples of such metaphors as "hearth", "hot spot", "political arena", "economic support", "information explosion" can be easily found on the pages of the world press in different languages.

When conducting research in the field of media linguistics, it is important to use the linguistic features of media texts, methods of analysis that allow to determine the structure of media texts, analysis of the linguistic, methodological and genre features of media texts.

Media texts can be studied on the following grounds:

- Phonetic and phonological features of the text (more than one vowel, more than one consonant, incorrect pronunciation of words (intentionally), alliteration, assonance, etc.);

- Lexical and semantic features of the text (synonyms, figurative words, paronyms, antonyms, polysemantic words, obsolete words, new words, dialects, stable combinations (phrases, figurative expressions, proverbs and translations (metaphor, metonymy, diagnostics, i.e. intoxication, exaggeration, belittling, irony, retelling, sarcasm);

- morphological features of the text (various morphological suffixes added to words in the text serve to express different meanings in the text (respect, arrogance, stubbornness, pitching, neglect, border, ridicule), positive or negative attitude of the author to reality);

- Syntactic features of the text (syntactic parallelism, emotional speech, rhetorical interrogative speech, inversion, ellipsis, gradation, antithesis, differentiation, analogy). (12, 69)

The review of methods for studying media texts ended in practice with the medialinguistic method, the essence of which is to identify and describe the patterns of interaction between oral and media series, study the features of the use of media-level symbols, as well as various options for combinations of elements of media texts at all levels: word, word - graphics, design - picture and so on. It is important to remember that multilevel media text components can be combined according to different principles images, additions, reinforcement, contrast, conflict of values, etc., in order to produce certain effects and increase the impact on the audience. $(6,508)$.

There are different views on the study of media texts. It depends on what aspect of the approach to studying them. The role of media texts, which are now actively used in all types of media, in the development of a common 
language is very important. Therefore, it is important to study media texts from different angles.

\section{CONCLUSION}

In conclusion, we note that there are different approaches to the study of media texts. Of these, the group of methods of linguistic analysis is important. When studying the linguistic, stylistic and genre features of media texts, the method of continuous text analysis is of great importance, which makes it possible to determine the rules for constructing a media text at a syntagmatic and methodological level. Also, the purpose of the method of stylistic analysis, which is important in the study of media texts, is to identify various methodological tools and their role in the implementation of the general communicative point of view of the media text.

\section{REFERENCES}

1. Avrorin V.A. Problems of studying the functional side of the tongue., -L.: 1975.

2. Bakieva. G. X., Teshabaeva D.M. Text in the media. Monograph. -T.: Turon-Iqbol, 2019.

3. Bakieva G.X., Teshabaeva D.M. The language of the media. -T.: 2020.

4. Vinokur G.O. O yazyke xudojestvennoy literatury. -M.: 1991.

5. Volodina M.N. Yazyk SMI as osobyy vid sotsialnogo vzaimoleystviya // Yazyk SMI as object mejdistsiplinarnogo issledovaniya. Ch.2. - M.: 2004.

6. Dobrosklonskaya T.G. Yazyk sredstv massovoy informatsii. $-\mathrm{M}$.: KDU, Dobrosvet, 2018. URL: https: // bookonlime.ru/node/509/

7. Israel M.I., Tashmukhamedova L.I. The art of public speaking. -T.: 6, Publisher. 2019.
8. Sa'dullaev S.D. Yazyk i stil sredstv massovoy informatsii.- T .: 2002.

9. Modern media text: uchebnoe posobie / otv. ed. N.A. Kuzmina. - Omsk, 2011.

10. Abdusattorov R., Language and style of mass media. Study guide. -T.: University. 2006.

11. Shomaksudov A., Rasulov I., Kungurov R., Rustamov $H$. Stylistics of the Uzbek language. - T.: Teacher. 1983.

12. Shamaqsudova S.X., Israel M.I. Written text in the media. Speech and discussion. - T.: Economics and Finance, 2018. 